\title{
Achievement Emotions and Barriers to Online Learning of University Students During the COVID- 19 Time
}

\author{
Phuong Vo ${ }^{1}$, Trang Lam ${ }^{2}$, Anh Nguyen ${ }^{3}$ \\ ${ }^{I}$ Faculty of International Languages \& Culture, Hoa Sen University \\ ${ }^{2}$ Faculty of International Languages \& Culture, Hoa Sen University \\ ${ }^{3}$ MA in psychology, HCMC University of Education \\ *Corresponding author. Email: phuong.vothibich@hoasen.edu.vn
}

\begin{abstract}
By definition, achievement emotions are emotions that are important and strongly linked with achievement activities or achievement outcomes. Researches have proved that achievement emotions are very important in the learning process of university students as they can affect learning performances, especially in the context of online learning due to the COVID-19 pandemic where students may encounter many barriers to learning in the virtual environment. In this study, an adapted version of the Achievement Emotions Questionnaire by Pekrun (2002) is used for the purpose of examining three positive achievement emotions, including enjoyment, hope, pride, and five negative achievement emotions including anger, anxiety, shame, hopelessness, and boredom. Students' emotional experiences are studied in online learning-related situations. Students' emotions are also examined in relation to four groups of barriers to learning in the virtual environment. The study involved the participation of 112 students who were currently joining online courses through the M-learning system at the time the survey was conducted. The results reveal that students experience barriers to online learning using the M-learning system at a low level in comparison with a high level of positive emotions and a medium level of negative emotions. From the results, some educational implications are drawn to minimize learners' negative emotions and help them overcome the barriers they encounter when studying online.
\end{abstract}

Keywords: achievement emotions, barriers, online learning.

\section{INTRODUCTION}

Due to the COVID-19 pandemic, schools all over the world have been required to close. It has also forced education to change dramatically to adapt to the new situation in which online learning plays a key role in the process of students' education.

More than 1.5 billion university students across Asia are forced to stay at home and keep going with their learning distantly via e-learning systems [1]. In Vietnam, during the COVID-19, 110 out of 240 universities, $70 \%$ of which are private universities, have employed e-learning as an alternative to direct physical classroom teaching during lockdown time [2].

Online learning is characterized by the use of various digital technological gadgets such as laptops or desktop computers, smartphones, iPads, and Internet access in teaching and learning remotely. It also implies that all the learning experiences are undertaken distantly through a synchronous and asynchronous learning environment.

Online learning is adopted as one of the most effective tools to continue educating students because it is proved to be an efficient way to deliver lessons with its tools compared to traditional face-to-face learning during the lockdown. In addition to this advantage, online learning is also supposed to be accessible to students from any location and time of their choice and suitable for a variety of learning styles.

However, in the progress of online learning and teaching, teachers and students also encounter many problems or barriers such as technology issues, difficulties in focusing on screens, and a sense of isolation. 
Those advantages and limitations may lead to students' positive or negative emotional experiences about the online learning environment. Academic emotions or achievement emotions are emotions that are tied directly to the learning process. It has been confirmed that students who participate in technology-enriched learning environments have a different set of emotions from students who join in traditional face-to-face courses [3-5]. In addition, achievement emotions have been proved to have many impacts on students' learning and performances, especially in online learning settings, where they may encounter many of the barriers in their learning process.

Considering the important effects which achievement emotions have on students' learning and performances in online learning contexts and the diversity in the types of emotions which learners experience during their participation in online courses, especially in the context of the COVID-19 pandemic where the mode of teaching and learning has been forcefully shifted, and online learning has become a necessity, this study was conducted for the purpose of answering the following three questions:

1. To what extent do students experience barriers to online learning?

2. What kinds of achievement emotions do students experience when learning online?

3. Is there a correlation between barriers to online learning and achievement emotions?

\section{LITERATURE REVIEW}

\subsection{Online learning and barriers to online learning}

\subsubsection{Online learning}

The term online learning has been illustrated as the learning experiences in which students get access to learning materials and have interactions with their teachers and peers via the use of computer technology [6-9].

When participating in online learning courses, learners can get access to full learning materials through a learning management system (LMS) and do their autonomous learning at their own pace asynchronously. In addition, to ensure online learning effectiveness, students should be able to communicate with their instructor and classmates synchronously via real-time online teaching tools (Real-Time Conference - RTC) such as Microsoft
Teams, Zoom, Webex, or Google Hangouts Meet. This is a chance for instructors to deliver the lesson content as well as to answer learners' questions and to give feedback to them.

\subsubsection{Barriers to online learning}

Barriers to online learning have attracted considerable attention in the literature. These studies revealed the most prominent barriers, including technical problems, delay in responses, feelings of isolation, course content problems, and factors related to individual learners.

Firstly, technical problems have long been identified as one of the challenges for online learners [10,11]. Galusha [10] revealed that students encounter many groups of barriers when they study online, the most popular of which is technical problems coming from the fact that learners lack experiences and training to learn in online settings. Song, Singleton, Hill and Koh [11] also proved technical problems to be one of the challenging characteristics of online learning context, the feeling of isolation, a general lack of time, and unclear course expectations, among other barriers.

Secondly, untimely feedback and responses from instructors are also one popular reported barrier to online learning settings as compared to face-to-face class discussions. Hara and Kling's [12] research reported that the students feel frustrated because they are not able to receive immediate responses from their teacher. Eom, Wen, and Ashill [13] reported similar results when examining students' satisfaction in university online courses. They concluded after their study that instructor feedback was a significant predictor of student success, whereas those factors such as course content and structure, learners' motivation, learning styles, classroom communication, and instructor assistance could turn out to be barriers if students are not satisfied.

Another barrier is the feeling of isolation from instructors and classmates when studying online. Vonderwell [14] stated that online learners reported a lack of contact with their teacher, especially one-toone rapport between students and instructors. Other studies showed that learners who took part in online courses stated to have the feeling of isolation because they don't have sufficient contact with their instructor and classmates. [15]. Similarly, senses of community in online learning were also highlighted by Rovai [16] as he concluded after his study that the stronger the online learners' sense of community, the less isolated they felt. In another research by Muilenburg 
and Berge [17], the authors suggested eight distinctive barriers which students encounter when they study online. These barriers include groups of components related to social interactions in online classroom contexts, cost of online courses, technical and computer-related issues, instructor-related issues, and individual learners' academic skills, motivation, time and support for studies. The results revealed that the most important barrier to students' learning in online contexts was social interaction and the least important one was academic skills.

Another significant predictor of students' satisfaction in the online educational experience is course content. Peltier, Drago, and Schibrowsky [18] suggested that teachers pay attention to six factors, including course content and structure, classroom interactions, instructors' facilitation, and feedback, and information delivery techniques to enhance students' satisfaction in learning.

The regression results of their study confirmed that course content and structure and instructors' facilitations were the most important barriers to students' learning process.

Last but not least, other factors related to individual learners, such as time constraints, support issues, and motivations, are identified as barriers to online learning settings [19]. Henderikx, Kreijns, Kalz concluded after their study that barriers to online learning can be categorized into four groups, including technical and online-learning-related skills, social interactions, course design, and time, support, and motivation.

An overview of barriers to online learning can be found in Figure 1 below.

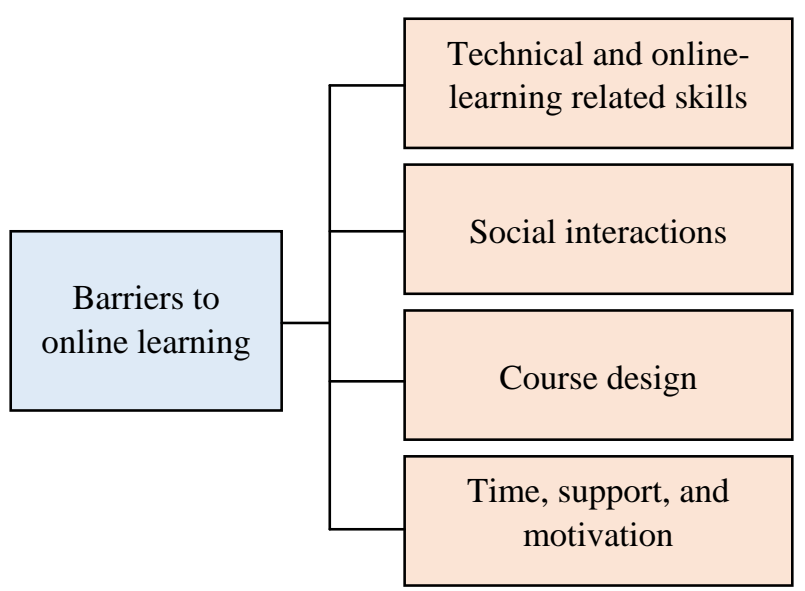

Figure 1 An overview of barriers to online learning (Henderikx, Kreijns, Kalz, 2018)

\subsection{Achievement emotions}

Achievement emotions are defined as emotions which are directly linked to achievement activities or achievement outcomes [20]. Pekrun and LinnenbrinkGarcia [20] have categorized achievement emotions, activity-related emotions, and outcome-related emotions. Pekrun, the founder of the Achievement Emotions Questionnaire (AEQ), achievement emotions are categorized into positive and negative emotions according to their valence or activating and deactivating emotions according to their degree of activation. Accordingly, there are four groups of emotions: activating - positive (enjoyment, hope, pride), deactivating - positive (relief); activating negative (anger, anxiety, shame); deactivating negative (hopelessness, boredom) (see Figure 2).

According to Pekrun et al., [21], achievement emotions can occur in three academic settings of the classroom, learning, and test or exam. In the present study, achievement emotions are investigated in the domain of learning only, whereas relief is excluded. In addition, those emotions which are examined in the current study are about the online learning environment via the use of the LMS Moodle and Microsoft Team Meeting.

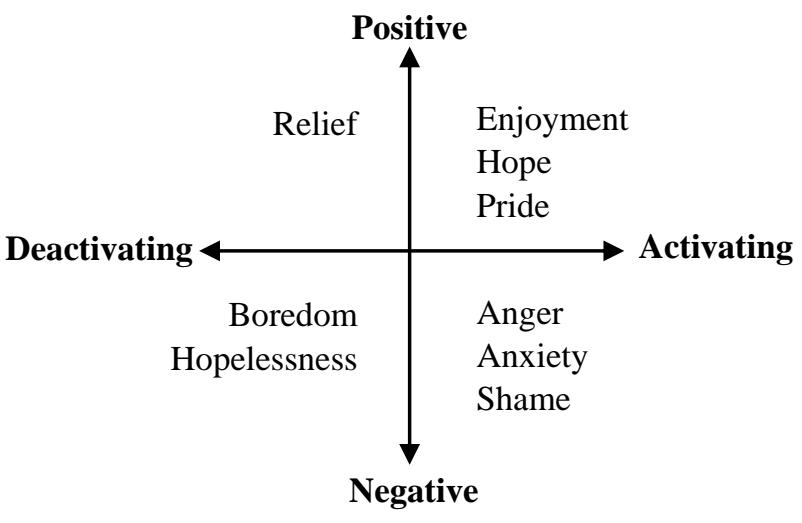

Figure 2 An overview of achievement emotions (Pekrun et al., 2002)

\subsection{Achievement emotions in online learning}

Achievement emotions experienced in online learning are different from those of traditional faceto-face and have an important impact on students' learning in online settings [22, 23].

Firstly, Artino [22] assumed that emotions are important factors that can contribute to students' learning, engagement, and performances in autonomous online learning settings.

It can be concluded that online learning environments are different from traditional physical 
classroom instruction regarding students' emotions, motivation, and learning outcomes [23]. In autonomous online learning settings, students explore courses' structure and feature individually at their own learning pace; thus their emotional experiences may be affected by the course content and also by the digital environment. This fact leads to the difference in achievement emotions between students who participate in online courses and traditional physical classrooms.

Butz et al. [5] supported this view in proving that online students using web conferencing reported significantly higher levels of anger, anxiety, and hopelessness in comparison with students who attend on-campus courses.

In addition, factors specific to online learning have been confirmed to lead to students having more positive or negative emotions [24]. For instance, technical problems experienced when using the LMS and the feeling of isolation when joining online classes often result in students feeling anxious, frustrated, and bored with their learning [25].

On the other hand, D'Errico et al. [26] revealed that the students who participate in different synchronous online-learning activities experienced a higher level of positive emotions are compared to those who have asynchronous interactions with a teacher and peers.

Overall, achievement emotions have been proved to have important impacts on students' learning and performances. Researchers also found differences in the types of emotional experiences at different levels which students have about different types of online learning activities. Thus, there is a necessity to figure out the types of emotions which the learners experience and the relationship between those emotions and barriers which the learners encounter during their online learning in the M-learning system at the research site.

\section{METHODOLOGY}

\subsection{Research design}

The study, by its nature, is descriptive quantitative research aiming to systematically report university students' achievement emotions and barriers to the online learning environment which they encountered during COVID-19 time. Quantitative data were collected using 5-point Likertscale questionnaires. 112 students who were attending online courses on the M-learning system at Hoa Sen University (HSU) participated in this survey. Convenience sampling was selected as the sampling design.

During the time the current study was conducted, all the online teaching and learning activities were run via LMS Moodle (M-learning system) and Microsoft Team Meetings due to a lockdown imposed on all universities during Corona Virus' pandemic. Students can get access to learning materials, exercises, discussion forums, and quizzes through courses according to subjects which are designed in MLS Moodle, namely the M-learning system. In addition, Real-time online teaching tool, in this case Microsoft Teams, was employed to hold synchronous interaction between instructors and students as well as between students.

\subsection{Participants}

The current study was conducted with the participation of 112 students from 6 classes. The students were currently attending online courses of English for International Communication (EIC) in the summer semester of the school year 2020-2021. The participants included 52 male and 60 female students. The participants were enrolled in 6 faculties within HSU: Tourism (8.9\%), Design \& Art (40.2\%), Economics \& Business (12.5\%), Finance \& Banking (5.4\%), IT (5.4\%), and Social Sciences (27.7\%).

\subsection{Data collection \& analysis}

In order to collect data, an online Vietnamese questionnaire that includes 66 5-point Likert Scale questions was administered to the participants. The purpose of the instrument is to collect data about four groups of barriers and 8 emotions that students may experience during their online study at university. Specifically, the first part of the questionnaire aims to collect information on barriers to online learning in four categories: technical and online-learning-related skills, social interactions, course design, and time, support, and motivation. This part of the instrument uses a 5-point Likert Scale from 'to a very small extent to 'to a very large extent. The second part of the instrument reports 3 positive achievement emotions of enjoyment, hope, pride and 5 negative emotions of anger, anxiety, shame, hopelessness, and boredom. In this part of the instrument, a 5-point Likert Scale of opinion from 'strongly disagree' to 'strongly agree' was employed. During the third week of the 7-week semester, the students voluntarily completed the questionnaire online via a link in the M-learning system. The data were downloaded onto Excel sheets, and descriptive statistics, as well as 
Correlation test, were used to analyze the relationship between achievement emotions and barriers to online learning.

\section{FINDINGS \& DISCUSSIONS}

\subsection{Barriers to online learning}

Table 1 reveals information on the barriers which the students encountered when studying in an online learning environment using the M-learning system. As can be seen from Table 1, the participants experienced barriers to online learning at a low level, with a total mean score of 2.3 .

Barriers related to social interaction seem to be a major problem for the participants in the current study, with a mean score of 3.2. Specifically, $48.3 \%$ of the students faced the feeling of isolation when studying online to a large and very large extent and $59 \%$ of them stated that they prefer to learn in a traditional face-to-face environment.

Barriers related to time, support, and motivation rank second in the list of barriers which are encountered by the participants with a mean score of 2.7 (average level). Most of the students experience barriers such as interruptions during study time or lack of personal motivation to a small and a moderate extent.

Barriers related to technical and online learning skills such as lack of skills for using the M-learning system or technical problems with the computer are regarded as a non-issue for the participants, with most of the choices falling for the scale from very small to small extent. The problem that the participants least experienced was a lack of skills in using the $\mathrm{M}$-learning system $(\mathrm{M}=1.78)$, with $74.1 \%$ of them experiencing this problem to a very small and small extent.

In addition, barriers related to course design, including low-quality materials, lack of timely feedback from the instructor or instructors who do not know how to teach online, also have a low mean score of 2.3. The least experienced problem is instructors do not know how to teach online, and the course content was bad ( $\mathrm{M}=1.8 ; 1.86$ respectively).

Table 1. Barriers to online learning

\begin{tabular}{|c|c|c|c|c|c|c|c|}
\hline Barriers & $\begin{array}{c}\text { To a } \\
\text { very } \\
\text { small } \\
\text { extent }\end{array}$ & $\begin{array}{c}\text { To a } \\
\text { small } \\
\text { extent }\end{array}$ & $\begin{array}{c}\text { To a } \\
\text { moderate } \\
\text { extent }\end{array}$ & $\begin{array}{l}\text { To a } \\
\text { large } \\
\text { extent }\end{array}$ & $\begin{array}{l}\text { To a } \\
\text { very } \\
\text { large } \\
\text { extent }\end{array}$ & Mean & S.D \\
\hline 1. Lack of skills for using the delivery system & 53.6 & 20.5 & 22.3 & 1.8 & 1.8 & 1.78 & .97 \\
\hline 2. Shy or lack of confidence & 40.2 & 15.2 & 35.7 & 4.5 & 4.5 & 2.18 & 1.1 \\
\hline 3. Unfamiliar with online learning technical tools & 40.2 & 26.8 & 20.5 & 10.7 & 1.8 & 2.07 & 1.0 \\
\hline 4. Technical problems with computer & 27.7 & 16.1 & 20.5 & 17.9 & 17.9 & 2.82 & 1.4 \\
\hline Technical and online learning skills & \multicolumn{7}{|c|}{ Mean $=2.25$} \\
\hline 5. Feeling of isolation & 20.5 & 13.4 & 17.9 & 17 & 31.3 & 3.25 & 1.5 \\
\hline 6. Lack of student collaboration & 22.3 & 20.5 & 25.9 & 15.2 & 16.1 & 2.82 & 1.3 \\
\hline 7. Lack of interaction/ communication among students & 18.8 & 18.8 & 21.4 & 19.6 & 21.4 & 3.06 & 1.4 \\
\hline 8. Prefer to learn in-person/ face-to-face & 12.5 & 8.9 & 19.6 & 18.8 & 40.2 & 3.65 & 1.4 \\
\hline Social interaction & \multicolumn{7}{|c|}{ Mean $=3.21$} \\
\hline 9. Lack of clear expectations/ instructions & 24.1 & 14.3 & 30.4 & 13.4 & 17.9 & 2.87 & 1.3 \\
\hline 10. Low-quality materials/ instruction & 36.8 & 15.2 & 30.4 & 13.4 & 14.3 & 2.73 & 1.3 \\
\hline 11. Unavailability of course materials & 26.8 & 16.1 & 28.6 & 8.9 & 19.6 & 2.79 & 1.4 \\
\hline 12. Lack of in-course support & 29.5 & 20.5 & 25.9 & 10.7 & 13.4 & 2.58 & 1.3 \\
\hline 13. Instructors do not know how to teach online & 59.8 & 10.7 & 18.8 & 10.7 & 0 & 1.80 & 1.0 \\
\hline 14. Lack of interaction with the instructor & 44.6 & 17.9 & 19.6 & 8.9 & 8.9 & 2.20 & 1.3 \\
\hline 15. Lack of timely feedback from the instructor & 51.8 & 8.9 & 23.2 & 10.7 & 5.4 & 2.09 & 1.3 \\
\hline 16. Lack of decent feedback & 48.2 & 17 & 25 & 7.1 & 2.7 & 1.99 & 1.1 \\
\hline
\end{tabular}




\begin{tabular}{|c|c|c|c|c|c|c|c|}
\hline 17. Course content was bad & 58 & 8.0 & 27.7 & 2.7 & 3.6 & 1.86 & 1.1 \\
\hline Course design & \multicolumn{7}{|c|}{ Mean $=2.30$} \\
\hline 18. Too many interruptions during study time & 30.4 & 13.4 & 27.7 & 13.4 & 15.2 & 2.70 & 1.4 \\
\hline 19. Lack of time in general & 39.3 & 14.3 & 17 & 11.6 & 17.9 & 2.54 & 1.5 \\
\hline 20. Family issues & 37.5 & 13.4 & 27.7 & 7.1 & 14.3 & 2.47 & 1.4 \\
\hline 21. Lack of support from family, friends & 37.5 & 16.1 & 22.3 & 8.0 & 16.1 & 2.49 & 1.4 \\
\hline 22. The learning environment is not very motivating & 30.4 & 8.9 & 30.4 & 14.3 & 16.1 & 2.77 & 1.4 \\
\hline 23. Lack of personal motivation & 28.6 & 13.4 & 25.9 & 17 & 15.2 & 2.77 & 1.4 \\
\hline 24. Own responsibility of learning & 28.6 & 6.3 & 27.7 & 21.4 & 16.1 & 2.90 & 1.4 \\
\hline Time, support and motivation & \multicolumn{7}{|c|}{ Mean $=2.66$} \\
\hline Barriers to online learning in & \multicolumn{7}{|c|}{ Mean $=2.34$} \\
\hline
\end{tabular}

In total, the students participating in the current study encountered barriers to online learning in the M-learning system at a low level. The barriers most frequently faced are barriers related to social interaction with the feeling of isolation.

This result is in line with the results proposed by Muilenburg \& Berge [16] in which a lack of social interaction was the most severe barrier perceived by the online learning participants.

On the contrary to the results in Song et al.'s [18] study, in which technical problems were reported to be the biggest challenge, barriers related to technical problems and course design were non-issue to the participants in the current study. This difference can be due to differences in participants' characteristics in each study. In the current study, the participants were all first-year students, and the majority of them had taken more than one online course because at the time the study was conducted, the students had had at least two semesters studying online due to the Corona virus' lockdown. On the other hand, the participants in Song et al.'s study were graduate students aged 20 to 50 , and $29 \%$ were first-time online learners. As a result, the students' levels of technology acceptance and mastery are different, which leads to differences in the result of the study.

\subsection{Online learning-related achievement emotions}

\subsubsection{Students' learning-related positive achievement emotions}

Information about students' learning-related positive achievement emotions in the online learning environment is reported in Table 2 below. Overall, students' learning-related positive achievement emotions are at a high level $(\mathrm{M}=3.3)$. Specifically, students' level of enjoyment and hope about their online learning are at high levels $(\mathrm{M}=3.3,3.4$ respectively), and students' pride is at an average level $(\mathrm{M}=3.2)$.

Students' choices related to online learningrelated enjoyment mostly range from average to high levels, with the highest mean score of getting physically excited when one's studies in M-learning are going well. For the other items such as acquiring new knowledge, dealing with the course material, getting a rush when studying well in the M-learning system, most of the answers fall into agreeing and strongly agree with scales $(\mathrm{M}=3.32,3.38,3.46$, respectively).

Table 2. Students' positive emotions

\begin{tabular}{|c|c|c|c|c|c|c|c|}
\hline \multirow{2}{*}{ Statements } & \multicolumn{5}{|c|}{ Percentage (\%) } & \multirow{2}{*}{ Mean } & \multirow{2}{*}{ S.D } \\
\hline & SD & $\mathbf{D}$ & $\mathbf{N}$ & $\mathbf{A}$ & SA & & \\
\hline 1. I enjoy the challenge of studying in M-learning. & 11.6 & 16.1 & 27.7 & 35.7 & 8.9 & 3.14 & 1.1 \\
\hline 2. I enjoy acquiring new knowledge in M-learning. & 10.7 & 8.9 & 28.6 & 41.1 & 10.7 & 3.32 & 1.1 \\
\hline 3. I enjoy dealing with the course material of M-learning. & 9.8 & 8.9 & 26.8 & 42.0 & 12.5 & 3.38 & 1.1 \\
\hline $\begin{array}{l}\text { 4. I study more than required in M-learning because I enjoy it so } \\
\text { much. }\end{array}$ & 14.3 & 21.4 & 32.1 & 23.2 & 8.9 & 2.91 & 1.1 \\
\hline
\end{tabular}




\begin{tabular}{|c|c|c|c|c|c|c|c|}
\hline 5. When my studies in M-learning are going well, it gives me a rush. & 5.4 & 12.5 & 27.7 & 40.2 & 14.3 & 3.46 & 1.0 \\
\hline $\begin{array}{l}\text { 6. I get physically excited when my studies in M-learning are going } \\
\text { well. }\end{array}$ & 4.5 & 8.0 & 21.4 & 50.0 & 16.1 & 3.65 & 0.9 \\
\hline
\end{tabular}

\begin{tabular}{|c|c|c|c|c|c|c|c|}
\hline Students' learning-related enjoyment & & & & ean $=$ & & & \\
\hline 7. I feel confident when studying in M-learning. & 8.0 & 9.8 & 25.9 & 44.6 & 11.6 & 3.42 & 1.0 \\
\hline $\begin{array}{l}\text { 8. The thought of achieving my learning objectives in M-learning } \\
\text { inspires me. }\end{array}$ & 5.4 & 10.7 & 28 & 6.0 & 41.1 & 3.48 & 1.0 \\
\hline $\begin{array}{l}\text { 9. My sense of confidence when studying in M-learning motivates } \\
\text { me. }\end{array}$ & 6.3 & 11.6 & 20.5 & 44.6 & 17.0 & 3.54 & 1.0 \\
\hline
\end{tabular}

\begin{tabular}{|c|c|c|c|c|c|c|c|}
\hline Students' learning-related hope & & & & $a=3$ & & & \\
\hline 10. I'm proud of my capacity to study in M-learning. & 4.5 & 13.4 & 23.2 & 42.9 & 16.1 & 3.53 & 1.0 \\
\hline $\begin{array}{l}\text { 11. Because I want to be proud of my accomplishments, I am very } \\
\text { motivated to study in M-learning. }\end{array}$ & 10.7 & 17.0 & 27.7 & 32.1 & 12.5 & 3.19 & 1.1 \\
\hline 12. When I excel at my work in M-learning, I swell with pride. & 15.2 & 19.6 & 24.1 & 26.8 & 14.3 & 3.05 & 1.2 \\
\hline Students' learning-related pride & \multicolumn{7}{|c|}{ Mean $=3.25$} \\
\hline Students' learning-related positive emotions & \multicolumn{7}{|c|}{ Mean $=3.34$} \\
\hline
\end{tabular}

Students' learning-related hope ranks highest among positive emotions, with a mean score of 3.4 (high level). All of the items related to hope to receive high mean scores, with the highest one being motivated by one's sense of confidence when studying in the online environment $(\mathrm{M}=3.65)$.

Students' pride is at an average level $(\mathrm{M}=3.2)$, which is also the lowest among positive achievement emotions. Only one item has the mean score at a high level which is pride in one's capacity to study in the M-learning system $(\mathrm{M}=3.53$, high level $)$. Other items receive mean scores at average levels $(\mathrm{M}=$ $3.19,3.05$ respectively).

\subsubsection{Students' learning-related negative achievement emotions}

Results concerning students' online learningrelated negative emotions are shown in Table 3 below. As can be seen from Table 3, students' negative emotions are at an average level with a total mean score of 3.21. Among 5 negative emotions, the students experienced boredom the most frequently $(\mathrm{M}=2.73$, average level) while anxiety ranks second with a fairly lower mean score $(\mathrm{M}=2.66$, average

\begin{tabular}{|c|c|c|c|c|c|c|c|}
\hline \multirow{2}{*}{ Statements } & \multicolumn{5}{|c|}{ Percentage (\%) } & \multirow{2}{*}{ Mean } & \multirow{2}{*}{ S.D } \\
\hline & SD & $\mathbf{D}$ & $\mathbf{N}$ & $\mathbf{A}$ & SA & & \\
\hline 13. Studying in M-learning makes me irritated. & 20.5 & 16.1 & 32.1 & 18.8 & 12.5 & 2.87 & 1.2 \\
\hline 14. I get angry while studying in M-learning. & 31.3 & 23.2 & 23.2 & 14.3 & 8.0 & 2.45 & 1.2 \\
\hline 15. I get annoyed about having to study in M-learning. & 34.8 & 15.2 & 31.3 & 12.5 & 6.3 & 2.40 & 1.2 \\
\hline 16. I get so angry when studying in M-learning that I feel like & 34.8 & 22.3 & 29.5 & 8.9 & 4.5 & 2.26 & 1.1 \\
\hline
\end{tabular}

level). Students' anger, shame, and hopelessness are at low levels ( $\mathrm{M}=2.53,2.52,2.59$ respectively).

For negative emotions, the highest mean score belongs to boredom $(M=2.7$, average level). Other emotions, including anger, anxiety, shame, hopelessness, are all at low levels $(\mathrm{M}=2.5,2.6,2.5$, 2.5 , respectively).

All of the items related to boredom are at an average level except for feeling depleted because of the boring materials $(\mathrm{M}=2.60$, low level). The item with the highest mean score is the feeling of drifting off because of the boring online learning environment $(\mathrm{M}=2.96)$. For other items related to boredom, most of the choices tend to fall to the disagree category of the scale.

Considering students' learning-related anxiety, which ranks second among negative emotions, most of the choices reveal that the students experienced anxiety at an average level except for two items of distracting oneself to reduce anxiety and heart races when time runs out $(\mathrm{M}=2.60$ and 2.33 respectively, low level).

Table 3. Students' negative emotions 


\begin{tabular}{|c|c|c|c|c|c|c|c|}
\hline $\begin{array}{l}\text { 17. When I sit at my desk for a long time to study M-learning, my } \\
\text { irritation makes me restless. }\end{array}$ & 27.7 & 15.2 & 22.3 & 27.7 & 7.1 & 2.71 & 1.3 \\
\hline Students' learning-related anger & \multicolumn{7}{|c|}{ Mean $=2.53$} \\
\hline 18. I get tense and nervous while studying in M-learning. & 25 & 18.8 & 29.5 & 12.5 & 14.3 & 2.72 & 1.3 \\
\hline $\begin{array}{l}\text { 19. I worry about whether I'm able to cope with all my work in M- } \\
\text { learning. }\end{array}$ & 21.4 & 15.2 & 33 & 19.6 & 10.7 & 2.83 & 1.2 \\
\hline $\begin{array}{l}\text { 20. The subject scares me since I don't fully understand the material in } \\
\text { M-learning. }\end{array}$ & 21.4 & 21.4 & 21.4 & 21.4 & 14.3 & 2.86 & 1.3 \\
\hline $\begin{array}{l}\text { 21. While studying in M-learning, I feel like distracting myself in } \\
\text { order to reduce my anxiety. }\end{array}$ & 31.3 & 17 & 22.3 & 19.6 & 9.8 & 2.60 & 1.3 \\
\hline 22. As time to study in M-learning runs out, my heart begins to race. & 34.8 & 26.8 & 17.9 & 11.6 & 8.9 & 2.33 & 1.3 \\
\hline $\begin{array}{l}\text { 23. Worry about not completing the material in M-learning makes me } \\
\text { sweat. }\end{array}$ & 26.8 & 23.2 & 19.6 & 16.1 & 14.3 & 2.68 & 1.3 \\
\hline Students' learning-related anxiety & \multicolumn{7}{|c|}{ Mean $=2.66$} \\
\hline 24. I feel ashamed when studying in M-learning. & 32.1 & 25.9 & 23.2 & 12.5 & 6.3 & 2.35 & 1.2 \\
\hline $\begin{array}{l}\text { 25. I feel ashamed that I can't absorb the simplest details when } \\
\text { studying in M-learning. }\end{array}$ & 26.8 & 18.8 & 29.5 & 17 & 8 & 2.61 & 1.2 \\
\hline $\begin{array}{l}\text { 26. I feel ashamed because I am not as adept as others in studying in } \\
\text { M-learning. }\end{array}$ & 25.9 & 23.2 & 25 & 12.5 & 13.4 & 2.64 & 1.3 \\
\hline $\begin{array}{l}\text { 27. I feel embarrassed about not being able to fully explain the } \\
\text { material in M-learning to others. }\end{array}$ & 31.3 & 17 & 23.2 & 17 & 11.6 & 2.61 & 1.3 \\
\hline $\begin{array}{l}\text { 28. I feel ashamed when I realize that I lack the ability to study in M- } \\
\text { learning. }\end{array}$ & 28.6 & 27.7 & 23.2 & 15.2 & 5.4 & 2.41 & 1.2 \\
\hline Students' learning-related shame & \multicolumn{7}{|c|}{ Mean $=2.52$} \\
\hline 29. I feel helpless when studying in M-learning. & 33 & 21.4 & 26.8 & 11.6 & 7.1 & 2.38 & 1.2 \\
\hline $\begin{array}{l}\text { 30. I'm resigned to the fact that I don't have the capacity to master } \\
\text { the material in M-learning. }\end{array}$ & 25.9 & 17 & 25 & 22.3 & 9.8 & 2.73 & 1.3 \\
\hline $\begin{array}{l}\text { 31. I feel so helpless that I can't give my studies in M-learning my } \\
\text { full efforts. }\end{array}$ & 33 & 14.3 & 23.2 & 18.8 & 10.7 & 2.60 & 1.3 \\
\hline $\begin{array}{l}\text { 32. I wish I could quit because I can't cope with my studies in M- } \\
\text { learning. }\end{array}$ & 26.8 & 16.1 & 23.2 & 21.4 & 12.5 & 2.77 & 1.3 \\
\hline $\begin{array}{l}\text { 33. My hopelessness undermines all my energy when studying in M- } \\
\text { learning. }\end{array}$ & 32.1 & 18.8 & 26.8 & 11.6 & 10.7 & 2.50 & 1.3 \\
\hline Students' learning-related hopelessness & \multicolumn{7}{|c|}{ Mean $=2.59$} \\
\hline 34. The M-learning material bores me to death. & 23.2 & 23.2 & 18.8 & 22.3 & 12.5 & 2.78 & 1.3 \\
\hline 35. Studying for my courses in M-learning bores me. & 25.0 & 14.3 & 32.1 & 17 & 11.6 & 2.76 & 1.3 \\
\hline 36. Studying in M-learning is dull and monotonous. & 23.2 & 20.5 & 25 & 21.4 & 9.8 & 2.74 & 1.3 \\
\hline $\begin{array}{l}\text { 37. While studying the boring M-learning material, I spend my time } \\
\text { thinking of how time stands still. }\end{array}$ & 25.9 & 17.9 & 25 & 21.4 & 6.3 & 2.57 & 1.2 \\
\hline $\begin{array}{l}\text { 38. The M-learning material is so boring that I find myself } \\
\text { daydreaming. }\end{array}$ & 22.3 & 21.4 & 28.6 & 18.8 & 8.9 & 2.71 & 1.2 \\
\hline 39. I find my mind wandering while I study in M-learning. & 18.8 & 21.4 & 25 & 27.7 & 7.1 & 2.83 & 1.2 \\
\hline $\begin{array}{l}\text { 40. Because I'm bored when studying in M-learning, I get tired } \\
\text { sitting at my desk. }\end{array}$ & 20.5 & 18.8 & 28.6 & 23.2 & 8.9 & 2.81 & 1.2 \\
\hline
\end{tabular}




\begin{tabular}{l}
\hline 41. The M-learning material bores me so much that I feel depleted. \\
\hline $\begin{array}{l}\text { 42. While studying in M-learning I seem to drift off because it's so } \\
\text { boring. }\end{array}$
\end{tabular}

\begin{tabular}{ll}
\hline Students' learning-related boredom & Mean $=2.75$ \\
\hline Students' learning-related negative emotions & Mean $=2.61$ \\
\hline
\end{tabular}

For most of the items concerning students' learning-related anger, shame, and hopelessness, the majority of students' choices stay in strongly disagree and disagree categories, which lead to low level mean scores. For instance, items such as getting angry and annoyed, feeling ashamed, feeling hopeless about online learning have more than $50 \%$ of choices for disagreeing and strongly disagree $(54 \%, 57.1 \%, 58 \%$, $56 \%$, respectively). On the other hand, there is a diversity in students' choices from strongly disagree to strongly agree for other items. For example, the participants reported the feeling of irritation the most frequently when $31.3 \%$ of them agreed to feel irritated, whereas $42.9 \%$ of them disagreed, and $32.1 \%$ were neutral about this idea. Similarly, considering the feeling of wanting to quit because one cannot cope with the online learning environment, $42.9 \%$ of the participants disagreed, $23.3 \%$ were neutral, and $33.9 \%$ agreed.

Overall, students' learning-related positive achievement emotions $(\mathrm{M}=3.3$, high level $)$ are higher than students' learning-related negative achievement emotions ( $\mathrm{M}=2.61$, average level). A paired sample t-test revealed that the participants reported significantly more positive emotions than negative ones $(\mathrm{df}=111, \mathrm{t}=5.785, \mathrm{p}<.0001)$.

A comparison in students' learning-related achievement emotions in the current study and Trang \& Dao's study [27] revealed some differences (see Figure 3). In the study by Trang \& Dao [27], students' learning-related achievement emotions are investigated in a face-to-face environment. As can be seen from Figure 2, all of the emotions experienced by the students from non-pedagogy majors in Trang \& Dao's study are higher than those of the participants in the current study except for anger. However, the difference between students' levels of anger is particularly small $(\mathrm{M}=2.4,2.5$ respectively).

In addition, concerning students' learning-related negative emotions, the participants in Trang \& Dao's study reported a higher level of activating emotions such as anxiety and shame than deactivating emotions (hopelessness and boredom) whereas, in the current study, the participants tend to have a slightly higher level of deactivating negative emotions although the participants' negative emotions are at an average level.

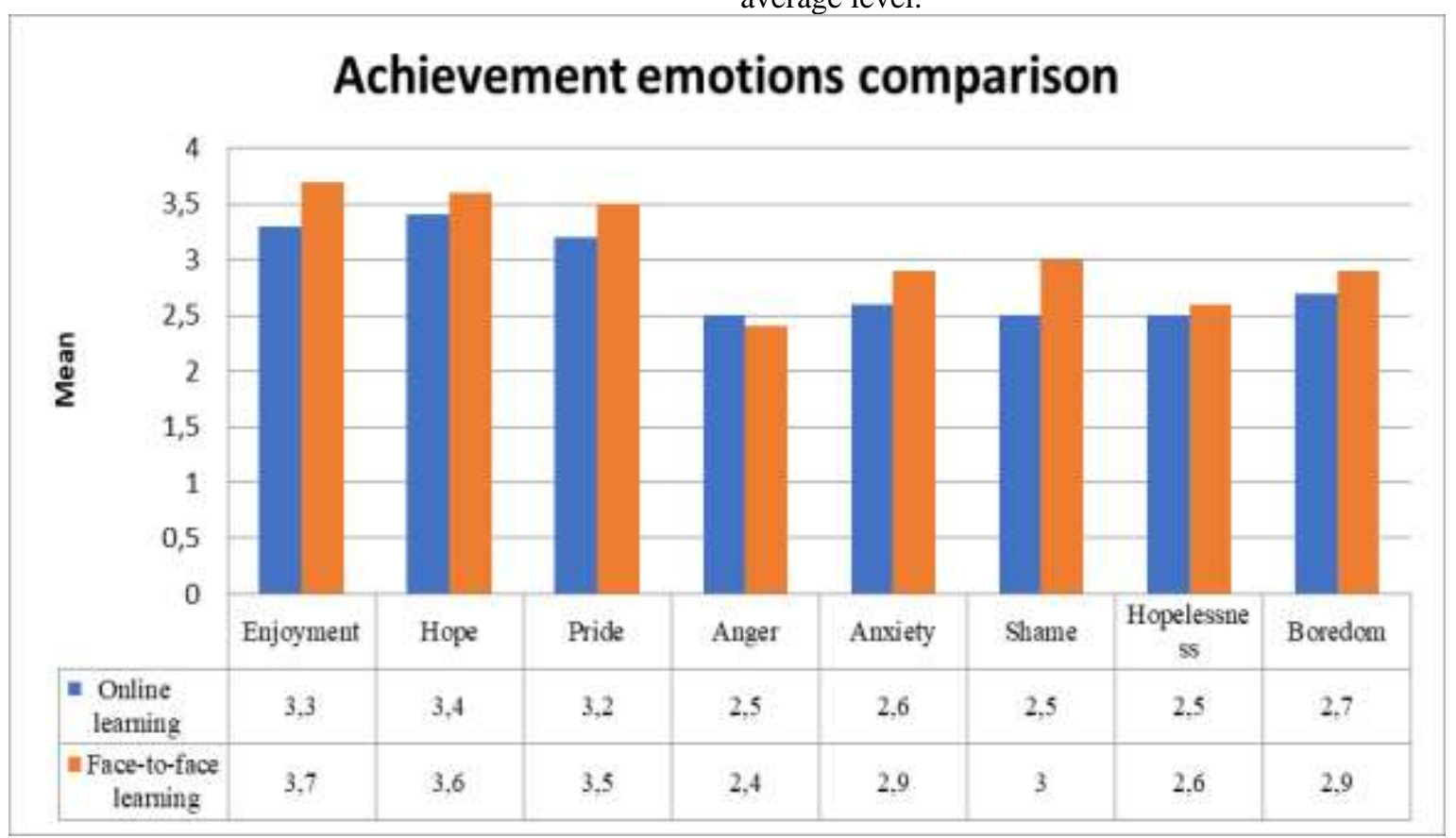

Figure 3: A comparison in achievement emotions between online and face-to-face environments 


\subsection{Correlations between barriers to online learning using the M-learning system and achievement emotions}

Table 4. Correlations between barriers to online learning and achievement emotions $(\mathrm{N}=112)$

\begin{tabular}{|c|c|c|c|c|}
\hline \multirow{2}{*}{ Variables } & \multicolumn{2}{|c|}{$\begin{array}{l}\text { Positive } \\
\text { emotions }\end{array}$} & \multicolumn{2}{|c|}{$\begin{array}{l}\text { Negative } \\
\text { emotions }\end{array}$} \\
\hline & 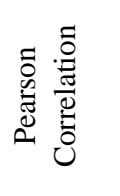 & 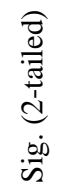 & 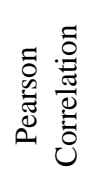 & 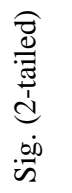 \\
\hline $\begin{array}{l}\text { Technical and } \\
\text { online learning } \\
\text { skills }\end{array}$ & $-.347 * *$ & .000 & $.441 * *$ & .000 \\
\hline Social interaction & $-.276^{* *}$ & .003 & $.371 * *$ & .000 \\
\hline Course design & $-.316^{* *}$ & .001 & $.473^{* *}$ & .000 \\
\hline $\begin{array}{l}\text { Time, support and } \\
\text { motivation }\end{array}$ & $-.273 * *$ & .004 & $.423 * *$ & .000 \\
\hline Total barriers & $-.347 * *$ & .000 & $.509 * *$ & .000 \\
\hline
\end{tabular}

Note: $* * \mathrm{p}<.01$

The relationship between barriers to online learning and online learning-related achievement emotions was investigated using Pearson correlation coefficient. Statistical analyses were performed, applying a significance level of 0.01 . The association between the four barrier components and positive as well as negative achievement emotions was shown in Table 4. Firstly, there was a small but statistically negative correlation between positive emotions and barriers to online learning, indicating that students who experienced a higher level of positive emotions encountered less severe barriers in learning online. On the other hand, increased levels of negative emotions have been associated with all four barriers to online learning. This result proves that students who have higher levels of negative emotions have more extreme encounters with barriers associated with 'technical and online learning skills,' 'social interaction,' 'course design,' and 'time, support and motivation.'

\subsection{Differences in achievement emotions between variables}

A series of independent sample t-test and oneway ANOVAs were used to verify the effects of the independent variables, including gender, preferred learning environment, and major, on students' achievement emotions (see Table 5). Results illustrated in Table 5 show that only one statistically significant difference is found in students' preferred learning environment with $p=.000$. For other variables, including gender and major, no statistically significant differences are found.

Table 5. Differences in achievement emotions $(\mathrm{N}=$ 112)

\begin{tabular}{|c|c|c|c|c|c|c|}
\hline 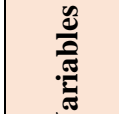 & Test & $\mathbf{N}$ & \multicolumn{2}{|c|}{$\begin{array}{l}\text { Positive } \\
\text { emotions }\end{array}$} & \multicolumn{2}{|c|}{$\begin{array}{l}\text { Negative } \\
\text { emotions }\end{array}$} \\
\hline \multirow{3}{*}{ 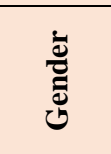 } & \multicolumn{2}{|c|}{$\begin{array}{c}\text { Independent } \\
\text { Sample T-Test }\end{array}$} & $\mathrm{T}$ & sig & $\mathrm{T}$ & Sig \\
\hline & Male & 52 & \multirow{2}{*}{.281} & \multirow{2}{*}{.248} & \multirow{2}{*}{.486} & \multirow{2}{*}{.441} \\
\hline & Female & 60 & & & & \\
\hline \multirow{4}{*}{ 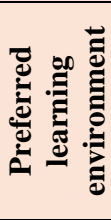 } & \multicolumn{2}{|c|}{$\begin{array}{c}\text { Independent } \\
\text { Sample T-Test }\end{array}$} & $\mathrm{F}$ & sig & $\mathrm{F}$ & Sig \\
\hline & Face-to-face & 81 & \multirow{3}{*}{10.1} & \multirow{3}{*}{.000} & \multirow{3}{*}{.986} & \multirow{3}{*}{.376} \\
\hline & Online & 28 & & & & \\
\hline & Others & 3 & & & & \\
\hline \multirow{7}{*}{$\stackrel{\grave{\Xi}}{\stackrel{\vec{J}}{\Sigma}}$} & \multicolumn{2}{|c|}{$\begin{array}{c}\text { One-way } \\
\text { ANOVA (F) }\end{array}$} & $\mathrm{F}$ & sig & $\mathrm{F}$ & Sig \\
\hline & Tourism & 10 & \multirow{6}{*}{.458} & \multirow{6}{*}{.807} & \multirow{6}{*}{1.63} & \multirow{6}{*}{.158} \\
\hline & $\begin{array}{c}\text { Design \& } \\
\text { Art }\end{array}$ & 45 & & & & \\
\hline & $\begin{array}{l}\text { Economics } \\
\text { \& Business }\end{array}$ & 14 & & & & \\
\hline & $\begin{array}{l}\text { Finance \& } \\
\text { Banking }\end{array}$ & 6 & & & & \\
\hline & IT & 6 & & & & \\
\hline & $\begin{array}{c}\text { Social } \\
\text { Sciences }\end{array}$ & 31 & & & & \\
\hline
\end{tabular}

\section{CONCLUSIONS}

The current study aimed at investigating barriers to online learning which the students encountered and their emotional experiences in the online learning environment, as well as the possible correlation between barriers and achievement emotions. The findings shed some light on understanding students' online learning and their emotions in order that the teaching and learning in the virtual environment can be enhanced. 
Firstly, the participants experienced barriers to online learning at a low level. Among the four barrier components, the participants experienced the most barriers related to social interactions. Other barrier components, including technical and online learningrelated skills, course design, time, support, and motivation, revealed a low level of experience, which means that those barriers were actually a non-issue for the participants. These results bring positive signals for both the instructors and the students. The students are confident in taking advantage of the online learning environment so as to have the best learning outcomes. The instructors can rely on students' ability to adapt to the online environment, the quality of the courses, and students' own motivation and responsibilities as success indicators for their teaching. However, instructors should increase teacher-students as well as students-students interactions so as to help students overcome those social interaction barriers in online learning and conduct their e-learning effectively.

Secondly, the students have a significantly higher level of positive emotions than negative ones. Students' learning-related positive emotions are at high levels, whereas their negative emotions are at average levels. Among three positive emotions, the emotion which the participants experienced at the highest level is learning-related hope. Considering negative emotions, boredom, which is deactivating, took the highest rank among the five negative emotions. With the belief that learning effectiveness will be enhanced in the condition that positive emotions are maximized, and negative emotions are minimized as much as possible [28, 29], the factors related to teaching-learning contexts of these emotions should be taken into consideration while designing and conducting online courses.

Last but not least, there is a statistically significant correlation between barriers to online learning and achievement emotions. Specifically, students who experience a higher level of positive emotions encounter barriers related to online learning less severely and vice versa. Thus, reliable and accessible technology, clear and explicit instructions, well-designed course content and structure, appropriate guidance and feedback, online communication with face-to-face meetings, and explicit criteria for excellence are all practical considerations for online learning effectiveness.

\section{AUTHOR CONTRIBUTIONS}

Vo Thi Bich Phuong and Lam Thuy Trang constructed the theoretical framework and the questionnaire for the study. Lam Thuy Trang carried out the survey. Vo Thi Bich Phuong was in charge of analyzing and describing the results concerning barriers to online learning. Nguyen Duc Anh took responsibility for analyzing achievement emotions. All authors provided feedback for the final research.

\section{REFERENCES}

[1] P.V.P. Ho, \& N.D.V. Thao., "CALL in Asia During Covid-19 and Models of E-Learning”. Proceedings of the 17th International Conference of the Asia Association of Computer-Assisted Language Learning (AsiaCALL 2021). Atlantis Press, 2021, 1, 10. DOI:

https://doi.org/10.2991/assehr.k.210226.001

[2] MOET, "The Information and Communications going along with Education and Training in the preventing Covid-19”, 2 April 2020. [Online]. Available:

https://en.moet.gov.vn/news/Pages/events.aspx? $\underline{\text { ItemID }=3933}$. [Accessed September 2021].

[3] L. M. Daniels and R. H. Stupnisky, "Not that different in theory: discussing the control value theory of emotions in online learning environments", The Internet and Higher Education, 15, 3, (2012) 222-226. DOI: http://dx.doi.org/10.1016/j.iheduc.2012.04.002.

[4] K. Regan, A. Evmenova, P. Baker, M.K. Jerome, V. Spencer, H. Lawson, \& T. Werner, Experiences of instructors in online learning environments: Identifying and regulating emotions. The Internet and Higher Education, 15, 3, (2012) 204-212. DOI: https://doi.org/10.1016/j.iheduc.2011.12.0 01 .

[5] N.T. Butz, R.H. Stupnisky, and R. Pekrun, Students' emotions for achievement and technology use in synchronous hybrid graduate programmes: a control-value approach. Research in Learning Technology, 23, 2015. DOI: 10.3402/rlt.v23.26097

[6] A. Benson, Using online learning to meet workforce demand: A case study of stakeholder influence. Quarterly Review of Distance Education, 3, 4, (2002) 443-452.

[7] S. Carliner, An overview of online learning (2nd ed.). Armherst, MA: Human Resource Development Press, 2004. 
[8] D. Conrad, Deep in the hearts of learners: Insights into the nature of online community. Journal of Distance Education, 17, 1, (2002) 1-19.

[9] T. Anderson, The Theory and Practice of Online Learning, Athabasca University Press, 2008.

[10] J. Galusha, Barriers to learning in distance education. Hattiesburg, MS: University of Southern Mississippi, 1998.

[11] L. Song, E.S. Singleton, J.R. Hill, and M.H. Koh, Improving online learning: Student perceptions of useful and challenging characteristics. Internet and Higher Education, 7, 1, (2004) $59-70$.

[12] N. Hara and R. Kling, Student distress in Webbased distance education. EDUCAUSE Quarterly, 3 (2001).

[13] S.B. Eom, H.J. Wen, N. Ashill, The Determinants of Students' Perceived Learning Outcomes and Satisfaction in University Online Education: An Empirical Investigation, Decision Sciences Journal of Innovative Education, 4, 2, (2006) 215-235.

[14] S. Vonderwell, An examination of asynchronous communication experiences and perspectives of students in an online course: A case study. Internet and Higher Education, 6, (2003) 77 90.

[15] R.H. Woods, How much communication is enough in online courses? Exploring the relationship between frequency of instructorinitiated personal email and learners' perceptions of and participation in online learning. International Journal of Instructional Media, 29, 4, (2002) 377 - 394.

[16] A.P. Rovai, Sense of community, perceived cognitive learning, and persistence in asynchronous learning networks. Internet and Higher Education, 5, (2002) 319 - 332.

[17] L.Y. Muilenburg and Z.L. Berge, Student barriers to online learning: A factor analytic study. Distance Education, 26, 1, (2005) 29-48. https://doi.org/10.1080/01587910500081269

[18] J.W. Peltier, W. Drago and J.A. Schibrowsky, Virtual Communities and the Assessment of Online Marketing Education. Journal of Marketing Education, 23, 1, (2003) 16 - 24.

[19] M. Henderik, K. Kreijns, and M. Kalz, A classification of barriers that influence intention achievement in MOOCs. In V. PammerSchindler, M. Pérez-Sanagustín, H. Drachsler,
R. Elferink, \& M. Scheffel (Eds.), Lifelong technology-enhanced learning. EC-TEL 2018. LNCS, 11082 (2018) 3-15.

[20] R. Pekrun, \& L. Linnenbrink-Garcia, Academic emotions and student engagement. In S. L. Christenson, A. L. Reschly, \& C. Wylie (Eds.), Handbook of research on student engagement (pp. 259-282), 2012. Springer Science \& Business Media. https://doi.org/10.1007/978-1-4614$\underline{2018-7 \quad 12}$

[21] R. Pekrun, T. Goetz, W. Titz, and R.P. Perry, Academic emotions in students' self-regulated learning and achievement: a program of qualitative and quantitative research. Educ. Psychol. 37 (2002) 91-105. DOI: 10.1207/S15326985EP3702_4

[22] A.R. Artino, Emotions in online learning environments: Introduction to the special issue. The Internet and Higher Education, 15, 3, (2012) 137-140.

[23] M. Stephan, S. Markus, and M. Gläser-Zikuda, Students' Achievement Emotions and Online Learning ins Teacher Education. Front. Educ., 4, (2019) $109 . \quad$ DOI: 10.3389/feduc.2019.00109

[24] A.R. Artino, \& K.D. Jones, Exploring the complex relations between achievement emotions and self-regulated learning behaviors in online learning. The Internet and Higher Education, 15, 3, (2012) 170-175. https://doi.org/10.1016/J.IHEDUC.2012.01.006

[25] M. Wosnitza and S. Volet, Origin, direction and impact of emotions in social online learning. Learning and Instruction, 15, (2005) 449-464.

[26] F. D'Errico, M. Paciello, and L. Cerniglia, When emotions enhance students' engagement in elearning processes. J. ELearn. Knowl. Soc. 12, (2016) 9-23. DOI: 10.20368/1971-8829/1144

[27] H.M. Trang, and M.H. Dao, "Students' achievement emotions", HCMC University of Education Journal of Science, 17, 2, (2020) 321 -328 .

[28] K. O’Regan, Emotion and e-learning. Journal of Asynchronous Learning Networks, 7, 3, (2003) $78-92$.

[29] R. Pekrun, The control-value theory of achievement emotions: assumptions, corollaries, and implications for educational research and practice. Educ. Psychol. Rev. 18, (2006) 315341. DOI: $10.1007 / \mathrm{s} 10648-006-9029-9$ 